\title{
Analysing the Relationship of Perceived Ease of Use, Perceived Usefulness, Attitude towards Usage and Behavioural Intention to use E-Government Services in State of Punjab
}

\author{
Manjot Kaur, PhD \\ Assistant Professor \\ Computer Science Application \\ Desh Bhagat University, Mandi Gobindgarh \\ Punjab, India
}

\begin{abstract}
E-Government initiatives in the state of Punjab are still at its early stage, although there is a progress in the implementation of this project. The main objective of this study is to scrutinize and examine empirically the relationship between perceived usefulness, perceived ease of use, attitude and behavioural intention to use e-government services by the citizens of state of Punjab. This paper aims to ascertain user's current attitude towards e-government initiatives in state of Punjab to discover whether there has been a shift since the previous research using TAM. In other words it seeks to determine the acceptance level Theoretical framework is TAM constructs: perceived ease of use, perceived usefulness, attitude toward usage and behavioural intentions to use and one external variable is Internet Usage. Main goal of this paper is identifying acceptance level of users for e-government initiatives. Although, a large portion of the academic literature focus on intention of use of e-government, comparatively little is known about why and under what circumstances, citizens adopt e-government services. (Carter L. \&., 2005) (Kumar, 2007) (Reddick, 2005) Hence, the central point of this research study is to analyse the relationship between perceived usefulness, perceived ease of use, attitude and behavioural intention to use e-government. After explaining the research objectives, this research paper discussed the literature review about the e-government. Based on the literature review, eight research hypotheses have been developed and a research model was proposed having four constructs. These four constructs and eight hypotheses were tested by a structured questionnaire. Questionnaires were distributed to 200 participants. Of the 200 surveys collected, 22 were considered unusable because they had many missing response items. The remaining 178 surveys were used in the analysis. The findings indicate that all the constructs contribute significantly to citizen adoption of e-government services in the state of Punjab.
\end{abstract}

\section{Keywords}

Perceived Usefulness, Perceived Ease of Use, Intention to use, E-Government Adoption, Attitude, TAM

\section{INTRODUCTION}

E-governance involves ICTs, especially the internet to enhance the delivery of government services to citizens, businesses \& government agencies as well. Besides the public sector, it also includes the management and administration of policies and procedures in private sectors. Except the delivery of faster services, internet also provides more transparency between the government and the citizens (Mittal \& Kaur, March 2013). The literacy rank of Punjab is 21 (Indian states ranking by literacy rate, 2011). Therefore, having such low level of literacy, it is very much difficult for the government to provide its services to such citizens via the means of Internet. The E-readiness is defined as the ability to use information and communication technologies to develop one's economy and welfare. According to the Global Information Technology Report 2012, the e-readiness rank of India is 69 with the score of 3.89 out of 10 (Mittal \& Kaur, EGovernance -A Challenge for India, March 2013). As per the Dataquest- IDC e-governance satisfaction study, the state of Punjab has $16^{\text {th }}$ rank for citizen satisfaction and $5^{\text {th }}$ rank in ereadiness (Singh \& Chander, 2014). Hence, the use of ICT in India is very low, likewise in Punjab as well. (Mittal \& Kaur, March 2013)

The e-government projects are implemented by government of India in a very efficient manner. As per the e-readiness reports of DIT (Department of Information Technology) of India, Andhra Pradesh, Punjab, Delhi, and Chandigarh \& Tamil Nadu are positioned as the leaders in the use of ICTs. Therefore, it can be said that, Punjab is one of the dominant state of India in ICT advancement. DoIT has been established in the state of Punjab. DoIT takes initiatives for the successful implementation of e-government projects in the state. The projects initiated by the state government \& DoIT are SUWIDHA, CSCs, e-Districts, VAHAN, (ii) SAARTHI (Mittal \& Kaur, E-Governance initiatives in the State of Punjab, 2013). E-government is one of the best ways to solve the social and economical problems that exists in state of Punjab. According to Deepak Ghaisas, former Chairman NASSCOM product forum and CEO India operations estimate "23 percent of government spending goes on defense and 46 percent on governance. It will actually boost the domestic tech industry, if a small fragment is spent on technology to streamline the process. (Dwivedi \& Bharti)

- E-Government will able to provide the government services to the common man in a worthwhile manner. Following are the some successful stories of e-government in Punjab-

(i) PAWAN (Punjab State Wide Area

Network)- PAWAN is the basic component for supporting E-government initiatives in Punjab. PAWAN is responsible as the backbone network for data, voice and video communication throughout the state. PAWAN lessens the 
communication cost and utilizes the services in a cost effective manner. It ensures that every citizen of the state has access to government services and information from anywhere and everywhere whenever they need it. (Mittal \& Kaur, EGovernance initiatives in the State of Punjab, 2013) (Singla \& Aggarwal, April 2012)

\section{(ii) SUWIDHA (Single User-friendly} Window Disposal Helpline for Applicants)This project was subsidized by GoP (Government of Punjab) and DOIT (Department of Information Technology), invented in August 2002 at Fatehgarh Sahib. This project is being implemented in all Deputy Commissioner's offices. SUWIDHA provides a user friendly, faster, cost-effective and adequate interface between the government and public. SUWIDHA has also provided the facility of native language i.e. Punjabi. By this project, citizen can capture the input at a single point, define a specified delivery date depending upon the type of services, accept the cash at the counter itself and delivers the required service at the same counter. SUWIDHA provides the following services-

$\begin{aligned} \text { i. } & \text { Issuance of Birth Certificate. } \\ \text { ii. } & \text { Issuance of Death Certificate. } \\ \text { iii. } & \text { Issuance of Affidavits. } \\ \text { iv. } & \text { Issuance of Permissions. } \\ \text { v. } & \text { Issuance of Indemnity Bonds. } \\ \text { vi. } & \text { Issuance of Surety Bonds. } \\ \text { vii. } & \text { Issuance of Bus Passes. } \\ \text { viii. } & \text { Issuance of Dependent Certificate. } \\ \text { ix. } & \text { Issuance of Licenses. } \\ \text { x. } & \text { Issuance of Nationality Certificates. } \\ \text { xi. } & \text { Issuance of Copy of a Document/ } \\ \text { xii. } & \text { Inspection of record and misc services. } \\ \text { xiii. } & \text { Issuance of ID card. } \\ \text { xiv. } & \text { Issuance of Marriage certificate. } \\ \text { xv. } & \text { Issuance of Un-married Certificate. } \\ \text { xvi. } & \text { Arm Licenses related services. } \\ \text { xvii. } & \text { Services to Pensioners. } \\ \text { xviii. } & \text { Character Verification. } \\ \text { xix. } & \text { Endorsement of SPA/GPA. } \\ \text { xx. } & \text { Appointment of Namberdar. } \\ \text { xxi. } & \text { Driving License related services. } \\ \text { xxii. } & \text { Registration of Vehicle related services. } \\ \text { xxiii. } & \text { Submission of Passport Applications. } \\ \text { xxiv. } & \text { Counter Signing of documents. (Mittal \& } \\ & \text { Kaur, E-Governance initiatives in the } \\ & \text { State of Punjab, 2013) }\end{aligned}$

(iii) CSC (Common Service Centre) - It is a community service centre for rural citizens at panchayat level covering six villages. CSC offer services as per the requirements of all the communities in its surroundings fivesix villages. As these centers are trying to offer every government department's service at one place. Therefore, each CSC is provided with computer, multifunctional printer, digital camera, internet connection and other related facilities. Through this CSCs have reduced the technical differences between rural and urban areas. (Mittal \& Kaur, E-Governance initiatives in the State of Punjab, 2013)

(iv) VAHAN and SARATHI- To offer citizen centric services, Punjab State Transport Department is the initiator in using Information Technology. Ten years ago, computerization of department started the implementation of
VAHAN and SARATHI software. All the services related to transport are being computerized and data is made available through internet or SMS for access by the public.

i. VAHAN- This software is developed by NIC Headquarters Delhi. It is used for register Vehicle, tax collection, issuing various certificates and permits and recording the fitness of vehicles.

ii. SARATHI- This software is also developed by NIC Headquarters Delhi. It is used by RLA (Registering and Licensing Authority). Services provided by SARATHI include learner license, permanent driving license, conductor's license and driving school license. (Mittal \& Kaur, E-Governance initiatives in the State of Punjab, 2013)

(v) e-Districts- Districts are the actual front-end of government where most government-to-citizen interactions take place. To improve this interaction and to enhance the efficiency of various departments at District level, the e-Districts project is initiated by Punjab Govt. This project ensures to provide the smooth delivery of services. This project is executed under NeGP (National e-Governance Plan). As per the guidelines, this project offers the following services:

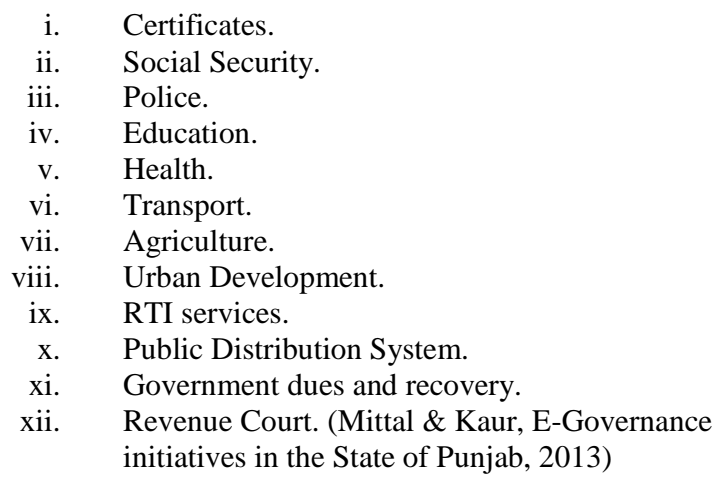

(vi). PRISM (Property Registration Information System Module) - To facilitate the land owners of the state, Revenue Department initiated the computerization of land records. This project simplifies the land registration process with high speed and efficiency at sub registrar offices across the state. The services offered by this project includes on the spot valuation of property, on the spot stamp \& registration fees calculations, online photo capturing of parties and witness along with Sub-Registrar and saving in data base, printing of photographs of parties in concern in the backside of stamp paper. Besides, user interface is available in native language i.e. Punjabi and English. (Singla \& Aggarwal, April 2012)

(vii). ITISP (Integrated Treasuries Information System Of Punjab) - In 2001, Government of Punjab developed ITISP for the computerization of Treasuries. Under this project, 18 district treasuries and 53 sub treasuries have been computerized. It is an online system for automation of treasuries and is accountable for verification of messenger by photo and signature. This project has lessened the time involved in calculation and enhances the accuracy and reliability of financial reports. (Singla \& Aggarwal, April 2012) 
(viii). PSEGS (Punjab State E-Governance

Society)- The prime aim of this project is to regulate the implementation of e-governance projects for the overall welfare of the citizens. PSEGS is responsible for setting up the necessary administrative, financial, legal and technical framework, implementation mechanism and resources in the state of Punjab. Sukhmani Societies are established under this project to provide the information and services to the citizens. (Singla \& Aggarwal, April 2012)

\section{CHALLENGES FOR E- GOVERNMENT IN PUNJAB}

There are numerous hurdles in the execution of e-government in Punjab. These can be classified as follows-

\subsection{Low Literacy Level}

Literacy means the capacity to read and write with understanding in any language. A person who can just read but cannot write cannot be rated as literate. The literacy rate of Punjab is very low, which is acting as a major challenge for egovernment adoption by the people.

\subsection{Low IT Literacy}

Majority of the people of Punjab are not literate and those who are literate, they do not have proper knowledge about the usage of Information Technology. So, in Punjab, such a low level of Information Technology is a major hurdle for egovernment adoption and acceptance by the people. To overcome this hurdle, people of Punjab must be made aware about the usage and benefits of Information Technology. (Malik, Priyanka, \& Verma, July 2014)

\subsection{Absence of Native Language}

The e-government applications are written in English language. This is one of the major reasons for the least acceptance and adoption of e-government as the acceptance and use of English language in Punjab is very low. Therefore, the e-government applications must be written in native language so that public may accept and adopt these applications very easily. (Malik, Priyanka, \& Verma, July 2014)

\subsection{Lack of User friendly websites}

Majority of the users of e-government websites are non experts. Such users do need proper instructions to access the applications in an appropriate way. If the government websites will not be user friendly then, people cannot accept e-government services at large scale. Therefore, government websites must be user friendly so that more and more people can use them easily and utilize the facilities offered by the government. This challenge can be overcome by designing government websites in an easier format and by creating user friendly interface. (Mittal \& Kaur, March 2013)

\subsection{Privacy and Security}

Privacy and security of an individual's personal data that user provides to acquire government services is one of the crucial barrier in the acceptance of e-government services. Majority of the people do not accept and adopt e-government services because of the fear that the information which they are going to share such as income, contact numbers, medical history, bank details etc can be misused. Inadequacy of security measures can restrict the development as well as adoption of e-government services. (Mittal \& Kaur, March 2013)

\subsection{Identification of Applications}

The next major challenge for e-government adoption is identification of e-government facilities by the citizens. It is a big challenge to have all the citizens well aware of the facilities offered by the e-government and have them to trust in it, so that citizens may accept and adopt these facilities in an easy and efficient manner. (Mittal \& Kaur, March 2013)

\subsection{Less Awareness}

Most of the people of Punjab are not aware of the advantages of e-government services. Government also does not pay much attention to make the people conscious about egovernment applications. Due to unawareness about the egovernment services, people cannot accept and adopt the technology. (Malik, Priyanka, \& Verma, July 2014)

\subsection{Non-Integration of Services}

E-government services provided by state and central government are not integrated properly. The information that lies in one department has no meaning to other department, thus, it creates the lack of communication and sometimes miscommunications as well. Therefore, because of non integration of services, people hesitate to adopt the egovernment services, as the lack of communication between departments result in public's harassment. (Kumar \& Bhanti, September 2012)

\subsection{Inequality}

In Punjab, there exist an inequality between the individuals, communities and businesses that have access to Information Technology and those that do not have such access. Economic poverty is closely related to the limited IT resources. A large segment of population is living below the poverty line that is why they cannot afford computers and internet connections to access the e-government services. On the contrary, the economically well stable people do not have adequate knowledge about the usage and benefits of e-government services. Therefore, this difference acts as a major challenge in the acceptance and adoption of e-government services. (Dwivedi \& Bharti)

\subsection{Low per Capita Income}

Per capita income means how much each individual receives in terms of money, of the yearly income generated in a country or state. In other words, it refers to what each individual receives if the yearly national income is divided equally between everyone. As compare to other states, per capita income of Punjab is low. That is major cause of non adoption and least acceptance of online services by the people of Punjab. (Mittal \& Kaur, March 2013)

3. MOTIVATIONS FOR THIS STUDY - The motivations for this study arise from the exhortations that occurred in the literature of e-government adoption and intention to use (Kumar, Mukerji, Butt, \& Persaud, 2007) Investigating citizen's responsiveness or reactions to egovernment services offered to public is needed. (Gil Garcia \& Martinez Moyano, 2007). Undoubtedly, offering up to date, effective and secure information on an e-government website will inspire more organizations and individuals to collect information, download forms, fill in and return files which cause a significant cost saving and efficiency gains for all participating parties. (Tung, 2005) (Huang, E-government Practices at Local Levels: An Analysis of U.S. Countries Websites, 2006) launch a strong call for more empirical research on user's acceptance of e-government services to improve its effectiveness and quality. (Kumar, Mukerji, Butt, $\&$ Persaud, 2007) argue that understanding why and how citizens use and interact with e-government websites is an important research exploration. Presently, the up-take and widespread use of e-government public services is still 
problematic in most countries (Verdegem \& Verleye, 2009). Finally, (Al-Adawi, Yousafza, \& Pallister, September,2005) hypothesizes that empirical evidence that shows how perceived usefulness and perceived ease of use is linked with intention to gather information or conduct transactions is needed. Therefore, it is obviously worthwhile to investigate this issue in more detail.

\section{RESEARCH OBJECTIVES}

The major objectives of this research are concerned with answering the following questions-

1. To what extent do the citizens of Punjab perceive that e-government system is useful and easy to use?

2. What is the relationship between perceived usefulness, perceived ease of use, attitude and behavioural intention to use e-government services?

3. To ascertain the user's acceptance level.

\section{THEORETICAL FRAMEWORK-}

Technology Acceptance Model is obtained from the theory of reasoned action (TRA) (Fishbein \& Ajzen, 1975) (Ajzen \& Fishbein, 1980). Technology Acceptance Model (TAM) is one of the various models that have been used by the researchers to forecast and explain the basic elements that inspire the users to accept and adopt new information technology systems (Davis, 1989).

As stated in TRA, the individual perspectives and subjective norms affect the user's behavioral intention, which in turn, affects his/her actual behaviour. Constructing upon this, TAM was proposed to describe and forecast user's acceptance of IT and IS systems by supposing that the constructs- perceived ease of use (PEOU) and perceived usefulness (PU) are the key determinants of IT and IS acceptance behaviour. (Davis, 1989, p. 320) defined perceived usefulness as "the degree to which a person believes that using a particular system would enhance his/her job performance", and defined perceived ease of use as "the degree to which a person believes that using a particular system would be free of effort". (Fishbein \& Ajzen, 1975, p. 216) defined behavioral intention as "the strength of one's intention to perform a specified behaviour". In TAM, the perceived usefulness of the system is forecasted to be positively affected by its perceived ease of use. TAM also proposed that all other external variables are fully mediated by PU and PEOU (Heijden, 2003). TAM states that, greater PU and PEOU of an IT/IS system will positively affect an attitude toward this system. The attitude, in turn, leads to a greater intention to use the system, which positively affects one's actual use of the system (Davis, 1989).

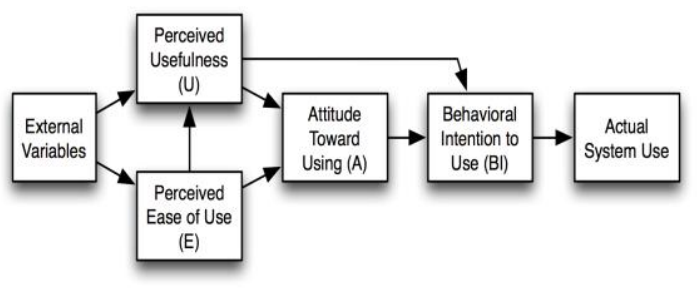

\section{RESEARCH MODEL AND} FORMULATING HYPOTHESIZES- The research model that guides this study is shown in following figure 1,the model examines the relationship between perceived usefulness, Perceived ease of use and Intention to use e-government services. The model is contsructed based on similar research models that appeared in the literature of egovernment adoptio. The related literature of e-government intention to use has been evaluated exactly to ensure that the significant factors that frequently appeared in the literarure were not missed. This research is concerned with exploring to what extent citizens of Punjab perceive that e-government is useful and easy to use. It also intends to examine the relationship between perceived uselfullness, perceived ease of use and intention to us e-government services offered to the citizens by the government. Besides, the differences between the citizens of Punajb in intention to use e-government for conducting transcations in terms of gender, age, level of education, computer usage and internet usage were main concerns of this research study. Therefore, the cross-sectional approch seems to be the most appropriate methd for examining this occurrence. The philosophy of the crosssectional approach is to study a particular occurrence at a particular time. Therefore, a large sample to carry out advanced data analysis is needed in order to ensure that the research results are generalizable. Questionnaires were distributed to 225 participants randomly chosen from Thapar University students, members of Patiala Bar Council and internet users in Punjab. A total of 200, $(88.88 \%)$ of surveys were returned. Of the 200 surveys collected, 22 were considered unusable because they had many missing response items. The remaining 178 surveys were used in the analysis.

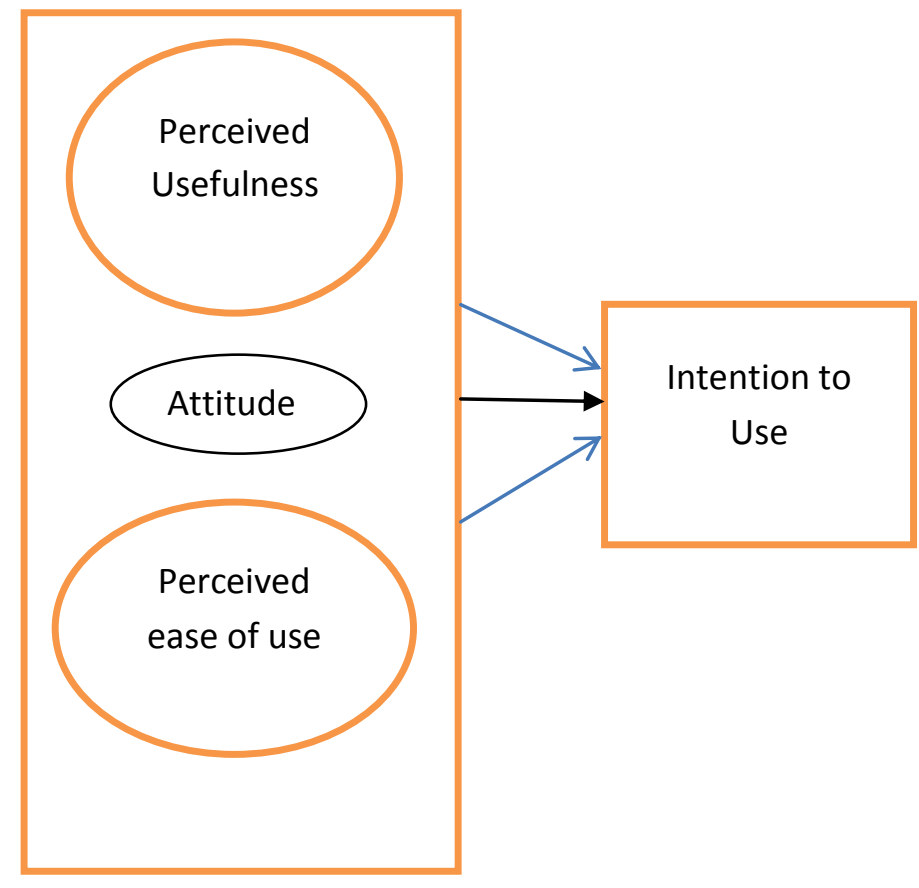

Figure 1. The Research Model

The research model has three constructs. The definition of these constructs are summarized as follows in Table 4.2

\begin{tabular}{|l|l|l|}
\hline Construct & Definition & Reference \\
\hline Perceived & The degree to & Davis(1989, \\
Usefulness & which a person & p.320) \\
& $\begin{array}{l}\text { feels that using a } \\
\text { specific system } \\
\text { would improve } \\
\text { his/her job } \\
\text { performance. }\end{array}$ & \\
\hline
\end{tabular}




\begin{tabular}{|l|l|l|}
\hline $\begin{array}{l}\text { Perceived } \\
\text { Ese of }\end{array}$ & $\begin{array}{l}\text { The degree to } \\
\text { which a person } \\
\text { feels that using a } \\
\text { specific system } \\
\text { would be free of } \\
\text { effort. }\end{array}$ & $\begin{array}{l}\text { Davis(1989, } \\
\text { p.320) }\end{array}$ \\
\hline $\begin{array}{l}\text { Behavioral } \\
\text { Intention } \\
\text { to Use }\end{array}$ & $\begin{array}{l}\text { Strength of one's } \\
\text { intention to } \\
\text { perform a } \\
\text { specified } \\
\text { behavior }\end{array}$ & $\begin{array}{l}\text { Fishbein and } \\
\text { Ajzen (1975, } \\
\text { p.216) }\end{array}$ \\
\hline Attitude & $\begin{array}{l}\text { An individual's } \\
\text { positive or } \\
\text { negative feelings } \\
\text { (evaluative } \\
\text { affect) about } \\
\text { performing the } \\
\text { target behavior }\end{array}$ & $\begin{array}{l}\text { Fishbeinand } \\
\text { p.216) }\end{array}$ \\
\hline
\end{tabular}

\section{LIST OF RESEARCH HYPOTHESES-}

Based on the literature review and assumptions of TAM, the following research hypotheses have been developed. These hypotheses will be tested in this study to empirically validate the proposed research model of e-government adoption in Punjab.

H1. There is a positive relationship between Perceived Ease of Use and Perceived Usefulness of e-Government initiatives.

H2. There is a positive relationship between Perceived Ease of Use and Attitude of e-Government initiatives.

H3. There is a positive relationship between Perceived Usefulness and Attitude of e-Government initiatives.

H4. There is a positive relationship between Perceived Usefulness and Behavioural Intention of use of e-Government initiatives.

H5. There is a positive relationship between Attitude and Behavioural Intention to Use e-Government initiatives.

H6. There is a positive relationship between Internet Usage and Perceived Ease of Use of e-Government initiatives.

H7. There is a positive relationship between Internet Usage and Perceived Usefulness of e-Government initiatives.

H8. There is a positive relationship between Internet Usage and Behavioural Intention to Use e-Government initiatives.

\subsection{DATA ANALYSIS}

Questionnaires were distributed to 225 participants randomly chosen from Thapar University students, members of Patiala Bar Council and internet users in Punjab. A total of 200, $(88.88 \%)$ of surveys were returned. Of the 200 surveys collected, 22 were considered unusable because they had many missing response items. The remaining 178 surveys were used in the analysis. $106(59.6 \%)$ of the respondents from the e-government adopters were male and $72(40.4 \%)$ were female. This indicates that the percentage of female who adopt e-government services in Punjab is higher than the percentage of male.

The highest age range was $26-45$ with $55 \%$. Followed by both
(21-25) and (46-55) group with $25.8 \%$ and $14.0 \%$. The percentage of the age group from above 55 years was $5.1 \%$. The highest percentage i.e. $80.3 \%$ of the respondents was from PG degree level. 19.1\% of the respondents were from Bachelor degree level, while $.6 \%$ of the respondents were from College degree level. $52.2 \%$ of the respondents belong to Hindu religion and $47.8 \%$ of the respondents were from Sikh religion. The majority of the respondents were Private Employee with $52.8 \%$. The percentage of Govt. Employee and students are $27.0 \%$ and $18.5 \%$ respectively, whereas the percentage of Not Employed was $1.7 \%$. Out of 178 respondents $69.7 \%$ of the respondents use Internet several times a day and $10.1 \%$ respondents used the Internet about once a week and few times a week as well. On the other hand $6.7 \%$ of the respondents used the Internet a few times a month, whereas $3.4 \%$ of the respondents used the Internet once in a month. The highest percentage i.e. $30.3 \%$ of the respondents used the e-government services once a month. $24.7 \%$ of the respondents used the e-government services a few times a week. $23.6 \%$ of the respondents used egovernment services a few times a month. $9.0 \%$ of the respondents used the e-government services about once a day and only $7.3 \%$ of the respondents used e-government services several times a day, whereas $5.1 \%$ of the respondents are revealed as non-users

Table 2 Respondent Background

\begin{tabular}{|c|c|c|c|}
\hline & & Frequency & Percent \\
\hline \multirow[t]{2}{*}{ Gender } & Female & 106 & 59.6 \\
\hline & Male & 72 & 40.4 \\
\hline \multirow[t]{4}{*}{ Age } & $21-25$ years & 46 & 25.8 \\
\hline & $26-45$ years & 98 & 55.1 \\
\hline & $46-55$ years & 25 & 14.0 \\
\hline & $\begin{array}{l}\text { Above } 55 \\
\text { years }\end{array}$ & 9 & 5.1 \\
\hline \multirow[t]{3}{*}{ Education } & $\begin{array}{l}\text { College } \\
\text { degree }\end{array}$ & 1 & .6 \\
\hline & $\begin{array}{l}\text { Bachelor } \\
\text { degree }\end{array}$ & 34 & 19.1 \\
\hline & PG degree & 143 & 80.3 \\
\hline \multirow[t]{2}{*}{ Religion } & Hindu & 93 & 52.2 \\
\hline & Sikh & 85 & 47.8 \\
\hline \multirow[t]{4}{*}{ Profession } & Student & 33 & 18.5 \\
\hline & $\begin{array}{l}\text { Governmen } \\
\text { t employee }\end{array}$ & 48 & 27.0 \\
\hline & $\begin{array}{l}\text { Private } \\
\text { employee }\end{array}$ & 94 & 52.8 \\
\hline & $\begin{array}{l}\text { Not } \\
\text { employed }\end{array}$ & 3 & 1.7 \\
\hline \multirow[t]{5}{*}{$\begin{array}{l}\text { Internet } \\
\text { Usage }\end{array}$} & $\begin{array}{l}\text { Once a } \\
\text { month }\end{array}$ & 6 & 3.4 \\
\hline & $\begin{array}{l}\text { A few } \\
\text { times a } \\
\text { month }\end{array}$ & 12 & 6.7 \\
\hline & $\begin{array}{l}\text { A few } \\
\text { times a } \\
\text { week }\end{array}$ & 18 & 10.1 \\
\hline & $\begin{array}{l}\text { About once } \\
\text { a day }\end{array}$ & 18 & 10.1 \\
\hline & $\begin{array}{l}\text { Several } \\
\text { times a day }\end{array}$ & 124 & 69.7 \\
\hline
\end{tabular}




\begin{tabular}{|c|c|c|c|}
\hline \multirow{6}{*}{$\begin{array}{l}\text { How often } \\
\text { access E- } \\
\text { Governmen } \\
\text { t Services }\end{array}$} & $\begin{array}{l}\text { Once a } \\
\text { month }\end{array}$ & 54 & 30.3 \\
\hline & $\begin{array}{l}\text { A few } \\
\text { times a } \\
\text { month }\end{array}$ & 42 & 23.6 \\
\hline & $\begin{array}{l}\text { A few } \\
\text { times a } \\
\text { week }\end{array}$ & 44 & 24.7 \\
\hline & $\begin{array}{l}\text { About once } \\
\text { a day }\end{array}$ & 16 & 9.0 \\
\hline & $\begin{array}{l}\text { Several } \\
\text { times a day }\end{array}$ & 13 & 7.3 \\
\hline & None & 9 & 5.1 \\
\hline
\end{tabular}

A reliability test was carried out using Cronbach's Alpha, which measures the internal consistency of research constructs. The recommended minimum acceptable limit of reliability "alpha" for exploratory study is .60 . The result of alpha values for all research constructs are above recommended value except IOU as shown in table 3 . Therefore, it can be concluded that the scale has internal consistency and reliability.
Table 3: Cronbach's Alpha for Research Constructs

\begin{tabular}{|c|c|c|}
\hline Scale & $\begin{array}{c}\text { No. of } \\
\text { Items }\end{array}$ & $\begin{array}{c}\text { Cronbach's } \\
\text { Alpha }\end{array}$ \\
\hline Attitude & 5 & .604 \\
\hline Ease of Use & 4 & .788 \\
\hline Intention to Use & 2 & .517 \\
\hline Usefulness & 4 & .685 \\
\hline Total & 15 & \\
\hline
\end{tabular}

7.2 T-TEST AND ONE-WAY ANOVA- First, the Independent T-test to examine if there are any differences between male and female citizens in terms of adopting and accepting e-government regarding all the variables such as Usefulness, Ease of Use, Attitude, Trustworthiness, Perceived Public Value, Culture and Intention of Use. Table 4 shows that for Usefulness variable (t-value $=-.515, \mathrm{p}$ value $=.607$ ), Ease of Use $(\mathrm{t}-\mathrm{value}=1.413, \mathrm{p}$ value $=.159)$, Attitude $(\mathrm{t}-\mathrm{value}=$ $.030, \mathrm{p}$ value $=.976)$ and Intention of Use $(\mathrm{t}$-value $=-.585, \mathrm{p}$ value $=.559)$. The $\mathrm{P}$-value to all the variables are $>.05$ i.e. nonsignificant. Thus, there are no-differences between male and female Punjabi Citizens in terms of accepting and adopting the e-services in relation to above said variables.

Table 4 Independent Sample T-test

\begin{tabular}{|l|l|l|l|r|r|r|c|}
\hline Variables & Gender & $\mathbf{N}$ & Mean & St. Dev & $\begin{array}{l}\text { Standad } \\
\text { Error } \\
\text { Mean }\end{array}$ & t-value & $\begin{array}{c}\text { Sig.(2- } \\
\text { tailed) }\end{array}$ \\
\hline \multirow{2}{*}{ Usefulness } & Male & 106 & 3.9953 & .40382 & .03922 & -.515 & .607 \\
\cline { 2 - 8 } & Female & 72 & 4.0382 & .62329 & .07345 & & \\
\hline Ease of Use & Male & 106 & 3.9292 & .60233 & .05850 & 1.413 & .159 \\
\cline { 2 - 8 } & Female & 72 & 3.7887 & .71170 & .08446 & & \\
\hline Attitude & Male & 106 & 4.1321 & .39220 & .03809 & .030 & .976 \\
\cline { 2 - 8 } & Female & 72 & 4.1296 & .61934 & .07299 & & \\
\hline $\begin{array}{l}\text { Intention Of } \\
\text { Use }\end{array}$ & Male & 106 & 4.1085 & .58961 & .05727 & -.585 & .559 \\
\cline { 2 - 8 } & Female & 72 & 4.1597 & .56185 & .06622 & & \\
\hline
\end{tabular}

Table 5.1 One Way ANOVA test for demographic information

\begin{tabular}{|c|c|c|c|c|c|}
\hline \multicolumn{7}{|c|}{ ANOVA for Age } \\
\hline Construct & $\begin{array}{c}\text { Sum of } \\
\text { Squares }\end{array}$ & df & $\begin{array}{c}\text { Mean } \\
\text { Square }\end{array}$ & F* $^{*}$ & Sig. \\
\hline Usefulness & 2.326 & 3 & .775 & 3.177 & .025 \\
\hline EOU & 1.520 & 3 & .507 & 1.203 & .310 \\
\hline Attitude & 4.548 & 3 & 1.516 & 6.791 & .000 \\
\hline IOU & 2.673 & 3 & .891 & 2.751 & .044 \\
\hline
\end{tabular}

Table 5.2 One Way ANOVA test for Profession

\begin{tabular}{|c|l|l|l|l|l|}
\hline \multicolumn{7}{|c|}{ ANOVA for Profession } \\
\hline Construct & $\begin{array}{c}\text { Sum of } \\
\text { Squares }\end{array}$ & $\mathbf{d f}$ & $\begin{array}{c}\text { Mean } \\
\text { Square }\end{array}$ & $\mathbf{F}^{*}$ & Sig. \\
\hline Usefulness & 4.813 & 3 & 1.604 & 6.985 & .000 \\
\hline EOU & 2.193 & 3 & .731 & 1.751 & .158 \\
\hline Attitude & 2.736 & 3 & .912 & 3.904 & .010 \\
\hline IOU & 10.066 & 3 & 3.355 & 11.924 & .000 \\
\hline
\end{tabular}


Table 5.3 One Way ANOVA test for Government Usage

\begin{tabular}{|c|l|l|l|l|c|}
\hline \multicolumn{7}{|c|}{ ANOVA for E-Government USage } \\
\hline Construct & $\begin{array}{c}\text { Sum of } \\
\text { Squares }\end{array}$ & df & $\begin{array}{c}\text { Mean } \\
\text { Square }\end{array}$ & F* $^{*}$ & Sig. \\
\hline Usefulness & 5.206 & 5 & 1.041 & 4.525 & .001 \\
\hline EOU & 9.114 & 5 & 1.823 & 4.775 & .000 \\
\hline Attitude & 4.687 & 5 & .937 & 4.166 & .001 \\
\hline IOU & 8.211 & 5 & 1.642 & 5.558 & .000 \\
\hline
\end{tabular}

Table 5.1 shows that demographic attribute age has no significant effects on user's responses on the dimensions "Ease of Use (EOU) and Intention of Use (IOU)" since the pvalue $>0.05$. On the other hand, age factor has a significant effect on the other dimensions such as "Usefulness $\mathrm{p}=.025$ ", "Attitude $p=.000$ ", since all these $p$-values are less than .05 , this indicates that age factor has a significant effect on Usefulness, and Attitude. Similarly, demographic attribute education has no significant effects on user's responses on the dimensions "Ease of Use (EOU) $p=.953$ ", "attitude $p=.388$ ", On the other hand, education factor has a significant effect on the other dimensions such as "Usefulness $\mathrm{p}=.031$ ", and "Intention of Use (IOU) $p=.000$ ", since all these $p$-values are less than .05 , this indicates that education factor has a significant effect on Usefulness, and IOU.

Table 5.2 shows that demographic attribute profession has no significant effects on user's responses on the dimensions "Ease of Use (EOU)" since the p-value>0.05. On the other hand, profession factor has a significant effect on the other dimensions such as "Usefulness $p=.000$ ", "Attitude $p=.010$ " and "Intention of Use (IOU) $\mathrm{p}=.000$ ", since all these $\mathrm{p}$-values are less than .05 , this indicates that profession factor has a significant effect on Usefulness, Attitude, and IOU. Similarly, demographic attribute Internet Usage has no significant effects on user's responses on the dimensions "Ease of Use (EOU)" and Attitude since the p-value>0.05. On the other hand, Internet Usage factor has a significant effect on the other dimensions such as "Usefulness $\mathrm{p}=.000$ ", and "Intention of Use (IOU) $p=.034$ ", since all these p-values are less than .05 , this indicates that Internet Usage factor has a significant effect on Usefulness, and IOU.

Table 5.3 shows that E-government Usage factor has a significant effect on all the dimensions such as "Usefulness $\mathrm{p}=.001$ ", "Ease of Use (EOU) $\mathrm{p}=.000$, "Attitude $\mathrm{p}=.001$ " and "Intention of Use (IOU) $\mathrm{p}=.000$ ", since all these $\mathrm{p}$-values are less than .05 , this indicates that E-government Usage factor has a significant effect on Usefulness, Ease of Use, Attitude and IOU.

\section{CONCLUSION}

The results have revealed that citizens of Punjab consider that the e-government system is useful and easy to use. The findings also show that perceived usefulness and perceived ease of use and attitude have a significant positive relationship with intention to use e-government. This result is consistent with (Tung, 2005; Carter \& Belanger, The Utilization of EGovernment Services: Citizen, Trust, Innovation and Acceptance Factors, 2005; Huang, E-government Practices at Local Levels: An Analysis of U.S. Countries Websites, 2006). Finally, the results suggest that the Punjabi citizen's gender and level of education play a critical role in using egovernment services. This result is inconsistent with (Van Dijk, Peters, \& Ebbers, 2008), who claim that socialdemographic and psychological factors do not influence egovernment acceptance and usage.

\section{REFERENCES}

[1] Adawi-AI, Yousafza, Z., \& Pallister, S. (September,2005). Concpetual Model of Citizen Adoption of E-government. Second International Coneference on Innovations in Information Technology (IIT'05), (pp. 1-10). Dubai, United Arab.

[2] Agarwal, R. (2000). Individual Acceptance of Information Technologies. In R. Z. (ed.), Framing the domains of IT management projecting the future through the past (pp. 85-104). Ohio: Pinnaflex Educational Resources Inc.

[3] Al-Adawi, Z., Yousafza, S., \& Pallister, J. (September,2005). Concpetual Model of Citizen Adoption of E-government. Second International Coneference on Innovations in Information Technology (IIT'05), (pp. 1-10). Dubai, United Arab.

[4] Belanger, F. \&. (2008). Trust and Risk in E-Government Adoption. Journal of Strategic Information Systems, vol.17, no.2, 165-176.

[5] Belanger, F., \& Carter, L. (2005). Trust and Risk in EGovernment Adoption. Eleventh Americas Conference on Information Systems (pp. 1955-1964). NE, USA: Omaha.

[6] Carter, L. \&. (2005). The Utilization of E-Government Services: Citizen, Trust, Innovation and Acceptance Factors. Information System Jouranl, vol 15, no.1 , 5-25.

[7] Choudrie, J., \& Dwivedi, Y. (2005). A Survey of Citizens Awareness and Adoption of E-Government Initiatives, the 'Government Gateway': A United Kingdom Perspective. eGovernment Workshop'05, (pp. 1-13). West London,UK.

[8] Dwivedi, S. K., \& Bharti, A. K. (n.d.). EGOVERNANCE IN INDIA - PROBLEMS AND ACCEPTABILITY. Jouranl of Theoretical and Applied Information Technology, 37-43.

[9] Economy of Punjab. (2013). Retrieved November 30, 2013, from http://www.mapsofindia.com/: http://www.mapsofindia.com/punjab/economy.html

[10] Gefen, D. (1997). Building Users Trust in Freeware Providers and Effects of this Trust on User's Perception of Usefullness, Ease of Use and Intended Use of Freeware. Georgia State University, USA: Ph.D. Thesis.

[11] Gefen, D. (2002). Reflections on the Dimensions of Trust and Trustworthiness among Online Consumer. Database for Advances in Information Systems, vol.33, no.3, 3853.

[12] Gil Garcia, J., \& Martinez Moyano, I. J. (2007). "Understanding the evolution of e-government:the influence of systems of rules on public sector dynamics". Governement Information Quarterly, vol.24, 266-290.

[13] Gilbert, D. B. (2004). Barriers and Benefits in the 
Adoption of E-Government. International Journal of Public Sector Management, vol.17, no.4, 286-301.

[14] Gupta, B., Dasgupta, S., \& Gupta, A. (2008). Adoption of ICT in a Government Organization in a Devloping Country: An Empirical Study. Journal of Strategic Information Systems, vol.17, no.2, 140-154.

[15] Huang, Z., \& Bwoma, P. (2003). An Overview of Critical Issues of E-government. Issues of Information Systems, vol.4, no.1, 164-170.

[16] Jaeger, P. (2003). The Endless Wire: E-government as Global Phenomenon. Government Information Quarterly, vol.20, no.4, 323-331.

[17] Kumar, P., \& Bhanti, P. (September 2012). Prospects of E-Governance in India. International Journal of Engineering and Innovative Technology, volume 2, issue 3, 335-339.

[18] Kumar, V. m. (2007). Factors for Successful Egovernment Adoption: a Conceptual Framwork. Electronic Journal of e-government, vol.5, no.1 , 63-76.

[19] Kumar, V., Mukerji, B., Butt, I., \& Persaud, A. (2007). Factors for Successful E-government Adoption: a Conceptual Framework. Electronic Journal of eGovernment, vol.5, no.1, 63-76.

[20] Mahajan, P. (2009). E-Governance initiatives in India with Special Reference to Punjab. Asia Pacific Journal of Social Sciences, 142-155.

[21] Malhotra, N., \& Peterson, M. (2006). Basic Marketing Research: A Decision Making Approach, 2nd edition. New Jersey: Prentice Hall.

[22] Malik, P., Priyanka, D., \& Verma, P. (July 2014). Challenges and Future Prospects for E-Governace in India. International Journal of Science, Engineering and Technology Research, volume 3, issue 7, 1964-1972.

[23] Mittal, P. D. (2013). E-Governance initiatives in the State of Punjab. International Journal of Research in Computer and Communication Technology, vol.2, issue 3, 108111.

[24] Mittal, P., \& Kaur, A. (2013). E-Governance initiatives in the State of Punjab. International Journal of Research in Computer and Communication Technology, vol.2, issue 3, 108- 111.

[25] Mittal, P., \& Kaur, A. (March 2013). E-Governance -A Challenge for India. International Journal of Advanced Research in Computer Engineering \& Technology, 11961199.

[26] Moon, M. (2002). The evolution of E-government among Municipalities: Rhetoric or Reality? Public Administration Review, vol.62, no.4, 424-433.

[27] Palvia, S. C., \& Sharma, S. S. (2007). E-Government and E-Governance: Definitions/Domain Frmaework and Status around the world. Retrieved July 10, 2011, from www.iceg.net: http://www.iceg.net/2007/books/1/1_369.pdf

[28] Park, S., \& Lemaire, J. (2011). Culture Matters: LongTerm Orientation and the Demand for Life Insurance. Philadelphia

[29] Patil, A. (2010, December 13). Going Local in India.
Retrieved November 28, 2014, from http://booksite.elsevier.com/:

http://booksite.elsevier.com/barnum/testingessentials/pdf s/06_Going_Local_in_India.pdf

[30] Pavlou, P. (2003). Consumer Acceptance of Electronic Commerce: Integrating Trust and Risk with the Technology Accepting Model. International Journal of Electronic Commerce, vol.7, no.3, 69-103.

[31] Reddick, C. (2005). Citizen Interaction with Egovernment: From the streets to servers. Government Information Quarterly, vol.22, no.1, 38-57.

[32] Riley, T. (2007). Strategies for the Effective Implementation of E-government Projects. Journal of Business and Public Policy, vol.1, no.1, 1-11.

[33] SSingh, A. (2013). E-Governance in Punjab:Overview. International Journal of Advanced Research in Management and Social Sciences, vol.2, no.6, 172-184.

[34] Singh, V. \&. (n.d.). E-Governance in Punjab- A User Staisfaction Study. International Journal of Research in IT, Management and Engineering, vol. 2, issue 1, 47-56.

[35] Singh, V., \& Chander, S. (2014). E-GOVERNANCE IN PUNJAB- A USER SATISFACTION STUDY International Journal of Research in IT, Management and Engineering, volume 2, issue 1, 47-56.

[36] Singh, V., \& Subhash, C. (2012). E-Governance in Punjab- A User Staisfaction Study. International Journal of Research in IT, Management and Engineering, vol. 2, issue $1,47-56$.

[37] Singh, V., \& Subhash, C. (2013). E-Governance in Punjab- A User Staisfaction Study. International Journal of Research in IT, Management and Engineering, vol. 2, issue $1,47-56$.

[38] Singla, S. K., \& Aggarwal, H. (April 2012). Impact and Scope of e-Governance Initiatives in State of Punjab (INDIA). International Journal of Computer Applications, volume 44, No-14, 5-9.

[39] Tung, L. \&. (2005). Adoption of Electronic Government Services Among Business Organizations in Singapore. Journal of Strategic Information Systems, vol.14, no.4, 417-440.

[40] Van Dijk, J., Peters, O., \& Ebbers, W. (2008). Explaining the acceptance and use of government internet services: A multivariate analysis of 2006 survey data in the Netherlands". Government Information Quarterly, vol.25, no.3, 379-399.

[41] Vankatesh, V., Morris, M., Davis, G., \& Davis, F. (2003). User Acceptance of Information Technology:Toward a Unified View. MIS Quarterly, vo. 27, no. $3,425-478$.

[42] VVenkatesh, V., \& Davis, F. (2000). A Theoretical Extension of the Technology Adoption Model: Four Longitudinal Field Studies. Management Science, vol.46, no.2, 186-204.

[43] Verdegem, P., \& Verleye, G. (2009). "User Centered Egovernment in Practice: A Comprehensive model for measuring user satisfaction". Government information Quarterly, vol.26, no.3, 487-497. 